\title{
Glass Waste Forms for the Na-bearing High Activity Waste Fractions
}

\author{
Krishna Vinjamuri
}

Published June 1995

\author{
Idaho National Engineering Laboratory \\ Lockheed Idaho Technologies Company \\ Idaho Falls, Idaho 83415
}

Prepared for the

U.S. Department of Energy

Assistant Secretary for Environmental Management

Under DOE Idaho Operations Office

Contract DE-AC07-94ID13223 


\section{DISCLAIMER}

This report was prepared as an account of work sponsored by an agency of the United States Government. Neither the United States Government nor any agency thereof, nor any of their employees, make any warranty, express or implied, or assumes any legal liability or responsibility for the accuracy, completeness, or usefulness of any information, apparatus, product, or process disclosed, or represents that its use would not infringe privately owned rights. Reference herein to any specific commercial product, process, or service by trade name, trademark, manufacturer, or otherwise does not necessarily constitute or imply its endorsement, recommendation, or favoring by the United States Government or any agency thereof. The views and opinions of authors expressed herein do not necessarily state or reflect those of the United States Government or any agency thereof. 


\section{DISCLAIMER}

Portions of this document may be illegible electronic image products. Images are produced from the best available original document. 


\begin{abstract}
Candidate experimental glasses for the Na-bearing high activity waste fractions were synthesized by crucible melting a mixture of reagent chemicals representative of the $\mathrm{Na}$-bearing waste, the pilot plant alumina calcine, and frit additives at 1200 or $1600^{\circ} \mathrm{C}$ for $2-5$ hours followed by air cooling of the melt. These glasses were characterized for density, elastic properties, viscosity, electrical resistivity, chemical durability, structural parameters, and glass phase separation. The results are discussed in this report.
\end{abstract}





\section{EXECUTIVE SUMMARY}

Glass waste forms are being considered for immobilization of the Na-bearing high activity waste fractions and the calcined alumina high-level wastes that are stored at the Idaho Chemical Processing Plant (ICPP). Candidate experimental glasses were synthesized by crucible melting a mixture of reagent chemicals representative of the $\mathrm{Na}$-bearing wastes, pilot plant alumina calcine, and frit additives at 1200 or $1600^{\circ} \mathrm{C}$ for $2-5$ hours followed by air cooling of the melt. The glass waste forms for immobilization of the Na-bearing wastes and the alumina calcine consisted of 35 and $50 \mathrm{wt} \% \mathrm{Na}$-Direct Vitrification high activity waste (Na-Dir.Vit-HAW), $35 \mathrm{wt} \% \mathrm{Na}$-freeze crystallization high activity waste (Na-FC-HAW), $35 \mathrm{wt} \% \mathrm{Na}$-precipitation high activity waste (Na-PPT-HAW), and 20-35 wt \% Na-Alumina waste. In general, the frit consisted of $88 \mathrm{wt} \% \mathrm{SiO}_{2}$, and $12 \mathrm{wt} \% \mathrm{~B}_{2} \mathrm{O}_{3}$. The wt \% of alumina and Na-bearing were 57 and $43 \mathrm{wt} \%$, respectively. The characteristics of the waste forms including density, elastic properties, viscosity, electrical resistivity, chemical durability, structural parameters, and phase separation were investigated. The measured densities ranged between 2.5 and $2.7 \mathrm{~g} / \mathrm{cm}^{3}$. The measured elastic moduli for the Na-Dir.Vit-HAW and Na-PPT glasses were 10.0 million and 10.6 million psi, respectively. These elastic moduli suggest that the glass samples are of similar strength and of similar thermal expansion coefficient to quartz. The estimated viscosities for Na-Dir.Vit-HAW, Na-PPT-HAW, and the Savannah River benchmark glasses are all less than 100 poise at $1400^{\circ} \mathrm{C}$. For $\mathrm{Na}-\mathrm{FC}-\mathrm{HAW}$ and $\mathrm{Na}$-Alumina glasses, the viscosities are high. In-can melting appears appropriate for these high viscosity alumino-silicate glasses. The estimated electrical resistivities are similar to that of the Savannah River benchmark glass. The 28-day MCC-1 total mass loss rates and the normalized elemental leach rates for aluminum, boron, calcium, cadmium, chromium, cesium, potassium, silicon, sodium, strontium, and zirconium are all low and less than $1 \mathrm{~g} / \mathrm{m}^{2}$-day. For the $20 \mathrm{wt} \% \mathrm{Na}$-Alumina glass the role of $\mathrm{Al}^{3+}$ ion in octahedral coordination appears to that of glass modifier. For the Na-FC-HAW, $\mathrm{Na}-\mathrm{Dir}$.Vit-HAW, and Na-PPT-HAW glasses, the role of $\mathrm{Al}^{3+}$ in tetrahedral coordination is that of glass former. The percent of tetrahedra ranged between 78 and $94 \%$ for the glasses investigated indicating that these glasses are durable. The number of corners shared per tetrahedra ranged between 3.2 and 3.9 for the glasses suggesting that these glasses are good (extended three-dimensional networks lacking periodicity according to the Zachariasen rule No. 4). Glass phase separation was not observed in any of the Na-bearing glasses investigated. In general, a glass without any phase separation is expected to be a durable glass. Even if some phase separation occurs, the glass may still be durable provided that the separated phases are durable. Because of the refractory components in the waste, it is a challenge to prepare low viscosity glasses. Optimization of the melt viscosity appears to be a challenge for the glass waste form processing. Corrosion of glass melter components is also an important concern. Further research and development is to be continued for glass transition temperatures, temperature time transition (TTT) diagrams, and radiation effects. 
$\checkmark$ 


\section{ACKNOWLEDGEMENTS}

This work is sponsored by the U.S. Department of Energy, Idaho Operations Office, under contract No. DE-AC07-94ID13223. The author wishes to thank D. V. Miley for SEM examination; Professor, David Howitt, University of California, Davis, for SEM and TEM examinations; B. A. Staples, S. V. Raman, W. B. Palmer, and J. D. Herzog for reviewing the report; H. C. Wood, B. A. Scholes, and P. A. Tullock for making the glasses, sample preparation, and MCC-1 leach testing; and S. R. Mickelsen and I. M. Moore for formatting and electronic publishing of the report. 



\section{CONTENTS}

ABSTRACT $\ldots \ldots \ldots \ldots \ldots \ldots \ldots \ldots \ldots \ldots \ldots \ldots \ldots \ldots \ldots \ldots \ldots \ldots \ldots \ldots$ iii

EXECUTTVE SUMMARY $\ldots \ldots \ldots \ldots \ldots \ldots \ldots \ldots \ldots \ldots \ldots \ldots$

ACKNOWLEDGEMENTS $\ldots \ldots \ldots \ldots \ldots \ldots \ldots \ldots \ldots \ldots \ldots$ vii

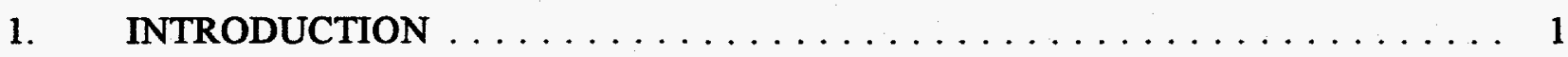

2. EXPERIMENTAL PROCEDURE, RESULTS, AND DISCUSSION $\ldots \ldots \ldots \ldots$

3. CONCLUSIONS AND RECOMMENDATIONS $\ldots \ldots \ldots \ldots \ldots \ldots \ldots, 21$

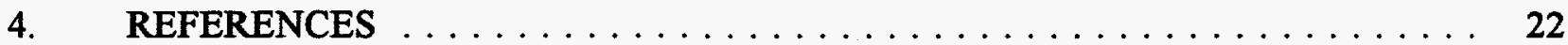

\section{TABLES}

1. Nominal Composition of Potential Na-bearing Waste Streams $\ldots \ldots \ldots \ldots \ldots 2$

2. Glass Quality Indicators for the Na-Dir.Vit Glass Waste Form . . . . . . . . 4

3. Glass Quality Indicators for the Na-FC-HAW Glass Waste Form . . . . . . . 5

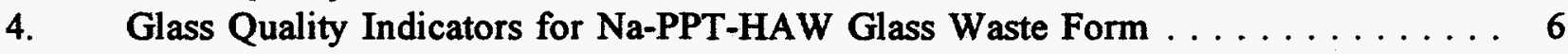

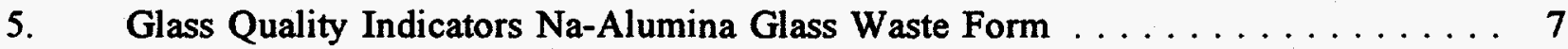

6. Solid Waste Loading (wt\%), Estimated Density, and Frit (wt\%) for the Glasses . . . . . . . . . . . . . . . 8

7. Nominal Composition of the Simulated Na-bearing

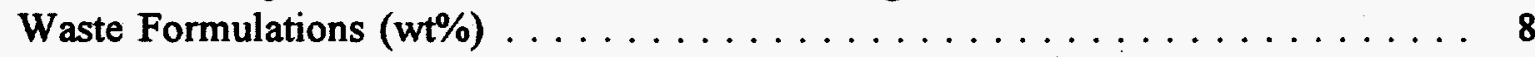

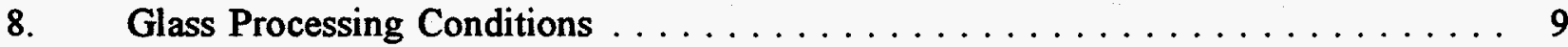

9. Comparison of Na-bearing Glass Properties with Savannah River Benchmark Glass . . . . . . . . . . . . . . . . . . . . . 13

10. The 28-day MCC-1 Total and Normalized Elemental Leach Rates for the Na-bearing Glasses in $\mathrm{g} / \mathrm{m}^{2}$-day. . . . . . . . . . . . . . . . . 14

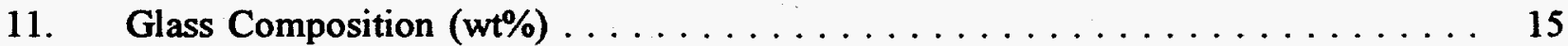

12. Glass Compositions in $\mathrm{Na}_{2} \mathrm{O}-\mathrm{Al}_{2} \mathrm{O}_{3}-\mathrm{SiO}_{2}$ and $\mathrm{Na}_{2} \mathrm{O}-\mathrm{B}_{2} \mathrm{O}_{3}-\mathrm{SiO}_{2}$ Systems

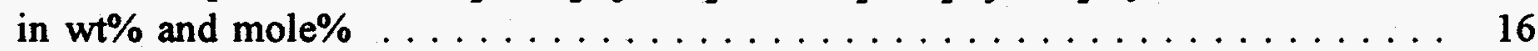

13. Structural Parameters for the Glasses $\ldots \ldots \ldots \ldots \ldots \ldots \ldots \ldots \ldots \ldots$

\section{FIGURES}

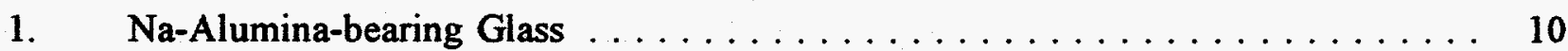

2. $\mathrm{Na}_{2} \mathrm{O}-\mathrm{Al}_{2} \mathrm{O}_{3}-\mathrm{SiO}_{2}$ Ternary Phase Diagram $\ldots \ldots \ldots \ldots \ldots \ldots \ldots \ldots \ldots$

3. $\mathrm{Na}_{2} \mathrm{O}-\mathrm{B}_{2} \mathrm{O}_{3}-\mathrm{SiO}_{2}$ Ternary Phase Diagram $\ldots \ldots \ldots \ldots \ldots \ldots \ldots \ldots .20$ 


\section{Glass Waste Forms for the Na-bearing High Activity Waste Fractions}

\section{INTRODUCTION}

Since 1963, the high level liquid waste (HLLW) from nuclear fuel reprocessing has been calcined into solid granules and stored onsite at the Idaho Chemical Processing Plant (ICPP). Thus, different types of calcines including fluorinel-sodium ( $\mathrm{Fl} / \mathrm{Na}$ ) blend, alumina, zirconia, zirconia-sodium $(\mathrm{Zr} / \mathrm{Na})$ blend and other calcines have been produced. In addition, as a result of process operations and decontamination activities at the ICPP, about 1.5 million gallons of radioactive liquid $\mathrm{Na}$-bearing waste were accumulated and stored in stainless-steel tanks contained in concrete vaults. Disposal of the Na-bearing wastes is one of the priority issues at the ICPP. Final disposal of the $\mathrm{Na}$-bearing and the calcined wastes in a geologic repository requires further consolidation of the wastes into a solid durable waste form. Glass or glass-ceramic ${ }^{1-10}$ waste forms are being considered for immobilization of the ICPP Na-bearing and calcined wastes. Several technologies have been identified for processing of the $\mathrm{Na}$-bearing waste into $\mathrm{Na}$-rich low activity waste (LAW) and high activity waste (HAW) containing actinides, fission products, and hazardous components. ${ }^{11}$ The processes identified for $\mathrm{HAW}$ are: 1) direct vitrification (Na-Dir.Vit-HAW), 2) Na-bearing high activity waste freeze crystallization (Na-FC-HAW); a process that uses the ability of ice crystals to reject salt to separate a solution into a salt rich and salt depleted stream, 3) Na-bearing precipitation high activity waste (Na-PPT-HAW); a process which uses the properties of certain components to be included in a solid phase formed from solution upon cooling or chemical addition, 4) separation of transuranium elements (Na-TRU-HAW); actinide separation through solvent extraction which is a process using counter-current aqueous and organic streams and changes in chemical conditions to selectively force a component into the organic phase and then to recover the component in an aqueous phase, and 5) blending of alumina calcine and the Na-bearing waste. In addition, four LAW streams are also identified as a result of denitrifying and solidifying the low active products from processing of the Na-bearing wastes 2) through 4) above. The compositions of the Na-bearing liquid waste streams are presented in Table 1. Simulated non-radioactive Na-bearing glasses were synthesized using reagent chemicals and the pilot plant alumina calcine (representative of the hot calcine in bin set 1), and characterized for density, elastic properties, chemical durability, glass structure, and phase separation. Temperature dependence of viscosities and electrical resistivities are modelled ${ }^{12}$ in the GlassForm computer spread sheet program. ${ }^{13,14}$ The formulation, processing, and glass waste form characteristics are discussed in this report. 


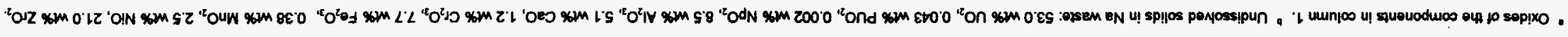

\begin{tabular}{|c|c|c|c|c|c|c|c|c|}
\hline $80 \%$ & & & 000 & LLO & $\forall 0$ & & 810 & $t+$ wn!nuos!z \\
\hline 6000 & & & $80^{\circ} 0$ & 810 & 820 & & 210 & $t+$ wnịuedn \\
\hline \multirow[t]{2}{*}{8000} & & & & & & & & t+ unịuelos \\
\hline & & & & & $10^{\prime} 0$ & & & $t+$ un!uounld \\
\hline \multirow[t]{2}{*}{ sto } & & & 810 & & 820 & & 210 & $\tau+10001 \mathrm{~N}$ \\
\hline & & & OL' & & 150 & & 210 & $z+$ Nunosow \\
\hline tho & & & 150 & & $\nabla 20$ & & Oto & $\varepsilon+$ wnuepq/10W \\
\hline 801 & & & 900 & & EEZ & & $866^{\circ} 0$ & $z+$ osourguew \\
\hline$\angle 20$ & & & tro & & $\$ 9^{\circ} 0$ & & szo & $z+$ pee \\
\hline 9L't & 2000 & & $68^{\circ} 0$ & $9-\exists \not z$ & OHE & & $\varepsilon Z^{\prime} L$ & $\varepsilon+$ บoil \\
\hline \multirow[t]{4}{*}{120} & $800^{\circ}$ & & 210 & 8810 & $6 \varepsilon 0$ & & $81^{\prime} 0$ & $\varepsilon+$ un!ाwos4ว \\
\hline & ro't & & & & & $00 \%$ & $66^{\circ} 0$ & 1- әрџ̣оㄴㅇ \\
\hline & & & & & & $00 \%$ & & $b+$ wniseo \\
\hline & & & & & & $0 Z^{\prime} 6 \mathrm{~L}$ & & brb-unues \\
\hline $80 \varepsilon$ & 060 & & $58 \%$ & $01 \cdot \exists 0^{\prime} 9$ & OL' & $\alpha z z$ & 812 & $z+$ unples \\
\hline $8 \varepsilon_{0} 0$ & & & $\nabla 20$ & $9-\exists 0 \%$ & & $\nabla 0$ & $D E 0$ & $z+$ un!upes \\
\hline$\angle \nabla 0$ & 600 & & $z 0$ & sto & 000 & $0 z^{\prime} 0$ & $O z^{\prime} 0$ & $\varepsilon+4000 \theta$ \\
\hline \multirow[t]{3}{*}{$\angle t^{\prime} 0$} & & & & $2 t=\exists 0 \%$ & & & & $z+$ un!ueg \\
\hline & & & & & & $0 \varepsilon \varepsilon$ & & SZL-Auoungur \\
\hline & & 200 & $\varepsilon+\varepsilon$ & sz & $\nabla \varepsilon \theta$ & $0 z^{\prime} 8$ & 192 & san \\
\hline $08 \%$ & $56 \%$ & 10 & & $01-30 \%$ & & 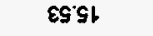 & 08. & $z-$ өqeyns \\
\hline 8929 & $\varepsilon \varepsilon 89$ & $886 \varepsilon$ & $82+2 z$ & $8-30 \%$ & $87 ' s$ & $09^{\circ}$ is & $\varepsilon \nabla \varepsilon t$ & $b+$ un!pos \\
\hline $0<6$ & torzl & $\varepsilon z^{\prime} 0$ & $\varepsilon t^{\prime} t$ & & $20 \%$ & 50.82 & 908 & $b+$ unp̧seqod \\
\hline $6 \varepsilon 0$ & $000 \angle$ & orsti & & & ISZZI & 00186 & $08 Z Z \varepsilon$ & 1- DIEAn \\
\hline$\varepsilon 0^{\circ} \varepsilon$ & $202 z$ & $\$ 0.0$ & $\angle F \cdot L$ & & & $0 \varepsilon^{\prime} b$ & $\varepsilon \varepsilon^{\prime}\llcorner$ & t- opuonis \\
\hline \multirow[t]{2}{*}{ otze } & 80.82 & 670 & S8'se & 6.302 & Er 0 & $0 t s s$ & EiLl & $\varepsilon+$ unu|⿱一𫝀口) $\forall$ \\
\hline & 871 & 100 & & & 10.6 & $21 \cdot t$ & $8 S^{\prime} \mathrm{L}$ & (H) p:OY \\
\hline $\begin{array}{c}\text { (soplyo) } \\
\varepsilon^{w / 6 x} \\
M V 7-n Y I-E N\end{array}$ & 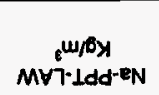 & 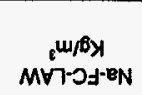 & 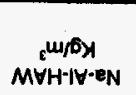 & $\begin{array}{c}\text { (sop!xo) } \\
\text { ew/BX } \\
\text { MYH-กYI-eN }\end{array}$ & 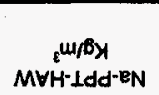 & $\begin{array}{c}\varepsilon^{m / \delta y} \\
M \forall H-\partial J^{-E N}\end{array}$ & 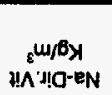 & squeuodwos \\
\hline
\end{tabular}




\section{EXPERIMENTAL PROCEDURE, RESULTS, AND DISCUSSION}

\section{Formulation}

The waste loading and frit (glass forming additives) composition were estimated using the GlassForm spread sheet computer program. ${ }^{13,14}$ The spread sheet ${ }^{13}$ uses: 1) weight percent of the waste stream, calcine or waste; 2) frit composition in wt\%; 3) assumed or estimated amount of components in the glass and crystalline phases in wt\%; 4) the free energy of hydration (kcal/mole) for the components in the glass phase; 5) weighted component density; 6) model for glass melt viscosity; and 7) model for electrical resistivity of the glass melt. The program calculates the desired glass quality ratios, 28-day Si leach rate in $\mathrm{g} / \mathrm{m}^{2}$-day, the waste form density in $\mathrm{g} / \mathrm{cm}^{3}$, the glass melt viscosity in poise, and the glass melt resistivity in ohm-cm. The glass quality ratios include: 1) ALKALI/ $\mathrm{B}_{2} \mathrm{O}_{3}, 2$ ) Silica/( $\left.\mathrm{B}_{2} \mathrm{O}_{3}+\mathrm{ALKALI}\right)$, 3) Silica/Total Amorphous, 4) (Alumina+Silica)/Amorphous, 5) Alumina/Amorphous, and 6) $\left(\mathrm{Na}_{2} \mathrm{O}+\mathrm{K}_{2} \mathrm{O}+\mathrm{CaO}\right) /\left(\mathrm{Al}_{2} \mathrm{O}_{3}+\mathrm{Fe}_{2} \mathrm{O}_{3}+\mathrm{B}_{2} \mathrm{O}_{3}\right)$. These ratios and desired ranges for glass waste forms are presented in Tables 2-5. The range of waste loading for each waste form was selected based on the number of ratios that lie in the desired range, and the 28-day MCC-1 silicon leach rate $\left(<1 \mathrm{~g} / \mathrm{m}^{2}\right.$-day). The solid waste loadings, glass densities, and frit compositions are presented in Table 6. The predicted solid waste loadings ranged between 20 and $50 \mathrm{wt} \%$. The frit (glass forming additives) consisted of $88 \mathrm{wt} \% \mathrm{SiO}_{2}$ and $12 \mathrm{wt} \% \mathrm{~B}_{2} \mathrm{O}_{3}$ for the Na-Dir.Vit-HAW, $\mathrm{Na}-\mathrm{FC}-\mathrm{HAW}$ and Na-Alumina glasses. For the Na-PPT-HAW glass, the frit composition was $84 \mathrm{wt} \% \mathrm{SiO}_{2}$ and $16 \mathrm{wt} \% \mathrm{~B}_{2} \mathrm{O}_{3}$. The frit compositions suggest that essentially the same frit $\left(88 \mathrm{wt} \% \mathrm{SiO}_{2}, 12 \mathrm{wt} \% \mathrm{~B}_{2} \mathrm{O}_{3}\right.$ ) can be used for all the Na-bearing waste streams that are synthesized and discussed in this report. Nominal oxide and fluoride compositions predicted by the GlassForm program are presented in Table 7. It appears that the compositions are typical of sodium-alumino-boro-silicate glasses. The inerts, such as $\mathrm{Al}_{2} \mathrm{O}_{3}, \mathrm{ZrO}_{2}, \mathrm{CaO}$, and $\mathrm{Cr}_{2} \mathrm{O}_{3}$, contribute positive free energies of hydration toward high chemical durability.

\section{Synthesis of Glass Waste Forms and Characterization}

The Na-bearing glasses were prepared by melting a 50 gram batch of the formulation (a mixture of reagent chemicals simulating Na-bearing waste and frit, or a blend of $57 \mathrm{wt} \%$ alumina calcine and $43 \mathrm{wt} \%$ of simulated Na-bearing waste) in an alumina crucible at $1200^{\circ} \mathrm{C}$ or $1600^{\circ} \mathrm{C}$ for 2-5 hours followed by air cooling in an insulated large crucible. The glass processing conditions are presented in Table 8. An ingot of clear Na-Alumina glass is shown in Figure 1. Monolith samples for density and leach testing were prepared. Samples for elastic moduli measurements for the waste form strength, SEM/EDS examination for any devitrification and for glass composition, and TEM samples for glass phase separation study were also prepared. The glasses were characterized for density, elastic properties, chemical durability, structural parameters, glass phases, and phase separation. Characterization techniques include density measurements using helium gas displacement pycnometry, 28-day MCC-1 leach test at $90^{\circ} \mathrm{C}$ in deionized water ${ }^{15}$, chemical analyses of leachates using inductively coupled plasma (ICP) and 
Table 2. Glass Quality Indicators for the Na-Dir.Vit Glass Waste Form

WASTE: Na-Dir.Vit-HAW, FRIT: $\mathrm{SiO}_{2}=88 \mathrm{wt} \%, \mathrm{~B}_{2} \mathrm{O}_{3}=12.0 \mathrm{wt} \%$

\begin{tabular}{||c|c|c|c|c|c||}
\hline $\begin{array}{c}\text { Ratio }=\text { Desired Range } \\
\text { LOAD (wt\%) }\end{array}$ & 20 & 25 & 30 & 35 & 50 \\
\hline $\mathrm{ALK} / \mathrm{B}=1-2.5$ & $1.29^{*}$ & $1.71^{*}$ & $2.19^{*}$ & 2.73 & 4.97 \\
\hline $\mathrm{S} /(\mathrm{ALK}+\mathrm{B})=2-3.5$ & $3.17^{*}$ & $2.67^{*}$ & $2.26^{*}$ & $1.92^{*}$ & $1.17^{*}$ \\
\hline $\mathrm{S} / \mathrm{TAM})=0.3-0.6$ & 0.71 & 0.67 & 0.63 & $0.58^{*}$ & $0.45^{*}$ \\
\hline$(\mathrm{A}+\mathrm{S}) / \mathrm{AM}=0.3-0.67$ & 0.77 & 0.74 & 0.72 & 0.69 & $0.60^{*}$ \\
\hline $\mathrm{A} / \mathrm{AM}<1.6$ & $0.48^{*}$ & $0.48^{*}$ & $0.48^{*}$ & $0.48^{*}$ & $0.48^{*}$ \\
\hline $28 \mathrm{Si} \mathrm{LR}<1 \mathrm{~g} / \mathrm{m}^{2}$-day & $0.03^{*}$ & $0.04^{*}$ & $0.05^{*}$ & $0.06^{*}$ & $0.13^{*}$ \\
\hline $\begin{array}{c}\mathrm{Na} \mathrm{O}_{2}+\mathrm{K}_{2} \mathrm{O}+\mathrm{CaO}^{*} \\
\left(\mathrm{Al}_{2} \mathrm{O}_{3}+\mathrm{Fe} \mathrm{O}_{3}+\mathrm{B}_{2} \mathrm{O}_{3}\right) \\
<<\text { or }=2 .\end{array}$ & $0.98^{*}$ & $1.18^{*}$ & $1.37^{*}$ & $1.54^{*}$ & $2.00^{*}$ \\
\hline Density in $\mathrm{g} / \mathrm{cm}^{3}$ & 2.40 & 2.42 & 2.44 & 2.46 & 2.52 \\
\hline Number of $* \mathrm{~s}$ & 5 & 5 & 5 & 5 & 6 \\
\hline
\end{tabular}

a $\mathrm{S}: \mathrm{SiO}_{2}, \mathrm{~B}: \mathrm{B}_{2} \mathrm{O}_{3}, \mathrm{~A}: \mathrm{Al}_{2} \mathrm{O}_{3}, \mathrm{AM}:$ Amorphous, TAM: Total amorphous, LR:Leach rate in $\mathrm{g} / \mathrm{m}^{2}$-day,

* indicates that the glass quality indicator (ratio) is within the desired range for a durable glass. 
Table 3. Glass Quality Indicators for the Na-FC-HAW Glass Waste Form

WASTE: Na-FC-HAW, FRIT: $\mathrm{SiO}_{2}=88 \mathrm{wt} \%, \mathrm{~B}_{2} \mathrm{O}_{3}=12.0 \mathrm{wt} \%$.

\begin{tabular}{|c|c|c|c|c|c|}
\hline $\begin{array}{c}\text { Ratio }=\text { Desired Range } \\
\text { ILOAD (wt } \%)\end{array}$ & 20 & 25 & 30 & 35 & 40 \\
\hline$A L K / B=1-2.5$ & 0.86 & $1.14^{*}$ & $1.47^{*}$ & $1.84^{*}$ & $2.27^{*}$ \\
\hline $\mathrm{S} /(\mathrm{ALK}+\mathrm{B})=2-3.5$ & 3.92 & $3.40^{*}$ & $2.95^{*}$ & $2.55^{*}$ & $2.21^{*}$ \\
\hline $\mathrm{S} / \mathrm{TAM})=0.3-0.6$ & 0.72 & 0.68 & 0.64 & $0.59 *$ & $0.55^{*}$ \\
\hline$(\mathrm{A}+\mathrm{S}) / \mathrm{AM}=0.3-0.67$ & 0.81 & 0.79 & 0.77 & 0.75 & 0.73 \\
\hline $\mathrm{A} / \mathrm{AM}<1.6$ & $1.04^{*}$ & $1.04^{*}$ & $1.04^{*}$ & $1.04^{*}$ & $1.04^{*}$ \\
\hline $28 \mathrm{Si} \mathrm{LR}<1 \mathrm{~g} / \mathrm{m}^{2}$-day & $0.03^{*}$ & $0.03^{*}$ & $0.03 *$ & $0.04^{*}$ & $0.05^{*}$ \\
\hline $\begin{array}{c}\mathrm{Na}_{2} \mathrm{O}+\mathrm{K}_{2} \mathrm{O}+\mathrm{CaO} / \\
\left(\mathrm{Al}_{2} \mathrm{O}_{3}+\mathrm{Fe}_{2} \mathrm{O}_{3}+\mathrm{B}_{2} \mathrm{O}_{3}\right) \\
<\text { or }=2\end{array}$ & $0.53^{*}$ & $0.63^{*}$ & $0.72^{*}$ & $0.80^{*}$ & $0.87^{*}$ \\
\hline Density in $\mathrm{g} / \mathrm{cm}^{3}$ & 2.47 & 2.50 & 2.54 & 2.57 & 2.61 \\
\hline Number of $*_{s}$ & 3 & 5 & 5 & 6 & 6 \\
\hline
\end{tabular}

a $\quad \mathrm{SiO}_{2}, \mathrm{~B}: \mathrm{B}_{2} \mathrm{O}_{3}, \mathrm{~A}: \mathrm{Al}_{2} \mathrm{O}_{3}, \mathrm{AM}$ :Amorphous, TAM:Total amorphous, LR:Leach rate in $\mathrm{g} / \mathrm{m}^{2}$-day,

* indicates that the glass quality indicator (ratio) is within the desired range for a durable glass. 
Table 4. Glass Quality Indicators for Na-PPT-HAW Glass Waste Form

WASTE: Na-PPT-HAW, FRIT: $\mathrm{SiO}_{2}=84 \mathrm{wt} \%, \mathrm{~B}_{2} \mathrm{O}_{3}=16.0 \mathrm{wt} \%$.

\begin{tabular}{|c|c|c|c|c|c|}
\hline $\begin{array}{c}\text { Ratio }=\text { = Desired Range } \\
\text { LOAD (wt\%) }\end{array}$ & 20 & 25 & 30 & 35 & 40 \\
\hline $\mathrm{ALK} / \mathrm{B}=1-2.5$ & 0.74 & 0.95 & $1.5^{*}$ & $1.40^{*}$ & $1.66^{*}$ \\
\hline $\mathrm{S} /(\mathrm{ALK}+\mathrm{B})=2-3.5$ & $2.69^{*}$ & $2.32 *$ & $2.00^{*}$ & $1.72^{*}$ & 1.49 \\
\hline $\mathrm{S} / \mathrm{TAM})=0.3-0.6$ & 0.72 & 0.69 & 0.65 & 0.62 & $0.58 *$ \\
\hline$(\mathrm{A}+\mathrm{S}) / \mathrm{AM}=0.3-0.67$ & 0.73 & 0.70 & $0.67^{*}$ & $0.64^{*}$ & $0.61^{*}$ \\
\hline $\mathrm{A} / \mathrm{AM}<1.6$ & $0.09 *$ & $0.09 *$ & $0.09^{*}$ & $0.09^{*}$ & $0.09 *$ \\
\hline $28 \mathrm{Si} \mathrm{LR}<1 \mathrm{~g} / \mathrm{m}^{2}$-day & $0.04^{*}$ & $0.04 *$ & $0.05^{*}$ & $0.07^{*}$ & $0.09^{*}$ \\
\hline $\begin{array}{c}\mathrm{Na}_{2} \mathrm{O}+\mathrm{K}_{2} \mathrm{O}+\mathrm{CaO} / \\
\left(\mathrm{Al}_{2} \mathrm{O}_{3}+\mathrm{Fe}_{2} \mathrm{O}_{3}+\mathrm{B}_{2} \mathrm{O}_{3}\right) \\
<\text { or }=2 \\
\end{array}$ & $0.64^{*}$ & $0.78^{*}$ & $0.91^{*}$ & $1.04^{*}$ & $1.16^{*}$ \\
\hline Density in $\mathrm{g} / \mathrm{cm}^{3}$ & 2.48 & 2.45 & 2.48 & 2.50 & 2.53 \\
\hline Number of *s & 4 & 4 & 6 & 6 & 6 \\
\hline
\end{tabular}

a S: $\mathrm{SiO}_{2}, \mathrm{~B}: \mathrm{B}_{2} \mathrm{O}_{3}, \mathrm{~A}: \mathrm{Al}_{2} \mathrm{O}_{3}, \mathrm{AM}:$ Amorphous, TAM:Total amorphous, LR:Leach rate in $\mathrm{g} / \mathrm{m}^{2}$-day,

* indicates that the glass quality indicator (ratio) is within the desired range for a durable glass. 
Table 5. Glass Quality Indicators Na-Alumina Glass Waste Form

WASTE: Na-Alumina, FRIT: $\mathrm{SiO}_{2}=88 \mathrm{wt} \%, \mathrm{~B}_{2} \mathrm{O}_{3}=12.0 \mathrm{wt} \%$.

\begin{tabular}{|c|c|c|c|c|c|}
\hline $\begin{array}{c}\text { Ratio } \\
\text { LOOAD }=\text { Desired Range }(\mathrm{wt} \%)\end{array}$ & 20 & 25 & 30 & 35 & 40 \\
\hline $\mathrm{ALK} / \mathrm{B}=1-2.5$ & 0.66 & 0.88 & $1.12^{*}$ & $1.40^{*}$ & $1.73^{*}$ \\
\hline $\mathrm{S} /(\mathrm{ALK}+\mathrm{B})=2-3.5$ & 4.36 & 3.84 & $3.38^{*}$ & $2.97^{*}$ & $2.60^{*}$ \\
\hline $\mathrm{S} / \mathrm{TAM})=0.3-0.6$ & 0.71 & 0.67 & 0.63 & $0.58^{*}$ & $0.54^{*}$ \\
\hline$(\mathrm{A}+\mathrm{S}) / \mathrm{AM}=0.3-0.67$ & 0.83 & 0.82 & 0.81 & 0.80 & 0.79 \\
\hline $\mathrm{A} / \mathrm{AM}<1.6$ & 1.90 & 1.90 & 1.90 & 1.90 & 1.90 \\
\hline $28 \mathrm{Si} \mathrm{LR}<1 \mathrm{~g} / \mathrm{m}^{2}-$ day & $0.02^{*}$ & $0.03^{*}$ & $0.03^{*}$ & $0.03^{*}$ & $0.04^{*}$ \\
\hline $\begin{array}{c}\mathrm{Na} \mathrm{O}_{2} \mathrm{O}+\mathrm{K}_{2} \mathrm{O}+\mathrm{CaO} / \\
\left(\mathrm{Al} \mathrm{O}_{2}+\mathrm{Fe} \mathrm{O}_{3}+\mathrm{B}_{2} \mathrm{O}_{3}\right) \\
<\text { or }=2 .\end{array}$ & $0.39^{*}$ & $0.45^{*}$ & $0.50^{*}$ & $0.54^{*}$ & $0.58^{*}$ \\
\hline Density in $\mathrm{g} / \mathrm{cm}^{3}$ & 2.47 & 2.51 & 2.55 & 2.59 & 2.63 \\
\hline Number of ${ }^{*} \mathrm{~s}$ & 2 & 2 & 4 & 5 & 5 \\
\hline
\end{tabular}

a S: $\mathrm{SiO}_{2}, \mathrm{~B}: \mathrm{B}_{2} \mathrm{O}_{3}, \mathrm{~A}: \mathrm{Al}_{2} \mathrm{O}_{3}, \mathrm{AM}:$ Amorphous, TAM:Total amorphous, LR: Leach rate in $\mathrm{g} / \mathrm{m}^{2}$-day,

* indicates that the glass quality indicator (ratio) is within the desired range for a durable glass. 
Table 6. Solid Waste Loading (wt\%), Estimated Density, and Frit (wt\%) for the Glasses

\begin{tabular}{|c|c|c|c||}
\hline Type of Solid Waste & $\begin{array}{c}\text { Load } \\
(\mathrm{wt} \%)\end{array}$ & $\begin{array}{c}\text { Estimated Density } \\
\left(\mathrm{g} / \mathrm{cm}^{3}\right)\end{array}$ & $\begin{array}{c}\text { Frit (wt\%) } \\
\mathrm{SiO}_{2}, \mathrm{~B}_{2} \mathrm{O}_{3}\end{array}$ \\
\hline Na-Dir.Vit-HAW & 35,50 & $2.46,2.52$ & 88,12 \\
\hline Na-PPT-HAW & 35 & 2.50 & 84,16 \\
\hline Na-FC-HAW & 35 & 2.57 & 88,12 \\
\hline Na-Alumina & $20,30,35$ & $2.20-2.40$ & 88,12 \\
\hline
\end{tabular}

Table 7. Nominal Composition of the Simulated Na-bearing Waste Formulations (wt\%)

\begin{tabular}{|c|c|c|c|c|}
\hline $\begin{array}{l}\text { Wastel } \\
\text { Loading }\end{array}$ & $\begin{array}{l}\text { Na-Dir-Vit-HAWI } \\
35 \text { wt\%, } 50 \text { wt\% }\end{array}$ & $\begin{array}{c}\text { Na-FC-HAWI } \\
35 w t \%\end{array}$ & $\begin{array}{l}\text { Na-PPT-HAWI } \\
35 w t \%\end{array}$ & 20, $\quad 30, \quad 35$ wt\% \\
\hline $\mathrm{Al}_{2} \mathrm{O}_{3}$ & $10.31,14.73$ & 15.68 & 28.57 & $8.70,13,48,16.00$ \\
\hline $\mathrm{B}_{2} \mathrm{O}_{3}$ & $0.20, \quad 0.29$ & 0.10 & 0.55 & $0.09, \quad 0.14,0.17$ \\
\hline $\mathrm{CaF}_{2}$ & $0.87, \quad 1.24$ & 1.32 & 0.96 & $0.12, \quad 0.19,0.22$ \\
\hline $\mathrm{CaO}$ & $0.35, \quad 0.50$ & 0.00 & 0.80 & $0.00, \quad 0.00,0.00$ \\
\hline CdO & $0.12, \quad 0.17$ & 0.06 & 0.32 & $0.04, \quad 0.06,0.07$ \\
\hline $\mathrm{Ce}_{2} \mathrm{O}_{3}$ & $0.00, \quad 0.00$ & 1.77 & 0.00 & $0.01,0.01,0.02$ \\
\hline $\mathrm{Cr}_{2} \mathrm{O}_{3}$ & $0.07, \quad 0.10$ & 0.00 & 0.20 & $0.03,0.05, \quad 0.05$ \\
\hline $\mathrm{Cs}_{2} \mathrm{O}$ & $0.00, \quad 0.00$ & 0.42 & 0.00 & $0.03, \quad 0.50,0.05$ \\
\hline $\mathrm{Fe}_{2} \mathrm{O}_{3}$ & $0.56, \quad 0.80$ & 0.00 & 1.55 & $0.12, \quad 0.19,0.22$ \\
\hline $\mathrm{K}_{2} \mathrm{O}$ & $3.09, \quad 4.41$ & 4.70 & 0.00 & $0.72,1.11,1.32$ \\
\hline $\mathrm{MnO}_{2}$ & $0.47, \quad 0.67$ & 0.00 & 1.30 & $0.12, \quad 0.18,0.22$ \\
\hline $\mathrm{MoO}_{3}$ & $0.05, \quad 0.07$ & 0.00 & 0.11 & $\begin{array}{lll}0.00 & 0.00 & 0.00\end{array}$ \\
\hline $\mathrm{Na}_{2} \mathrm{O}$ & $18.65,26.61$ & 10.41 & 0.00 & $4.40,6.82,8.09$ \\
\hline Nio & $0.05, \quad 0.07$ & 0.00 & 0.18 & $0.04,0.05,0.06$ \\
\hline Pbo & $0.09, \quad 0.13$ & 0.00 & 0.20 & $0.02, \quad 0.03,0.04$ \\
\hline $\mathrm{vo}_{3}$ & $0.05, \quad 0.07$ & 0.00 & 0.00 & $0.01, \quad 0.02,0.02$ \\
\hline $\mathrm{ZrO}_{2}$ & $0.08,0.14$ & 0.00 & 0.20 & $0.13,0.19,0.23$ \\
\hline $\mathrm{SiO}_{2}$ (additive) & $57.20,44.00$ & 57.20 & 54.60 & $74.98,67.81,64.04$ \\
\hline $\mathrm{B}_{2} \mathrm{O}_{3}$ (additive) & $7.80, \quad 6.00$ & 7.80 & 10.40 & $10.23,9.25,8.74$ \\
\hline
\end{tabular}


Table 8. Glass Processing Conditions

\begin{tabular}{|c|c|c|c|}
\hline Type of Waste & Temperature $\left({ }^{\circ} \mathrm{C}\right)$ & Time (hours) & Cooling $^{\mathrm{a}}$ \\
\hline Na-Dir.Vit-HAW & 1200 & 2 & Air Cooled \\
\hline Na-PPT-HAW & 1200 & 2 & Air Cooled \\
\hline Na-FC-HAW & 1200 & 2 & Air Cooled \\
\hline Na-Alumina & 1200,1600 & $2-5$ & Air Cooled \\
\hline
\end{tabular}

a A 50 gram batch of each formulation was heated in an alumina crucible and air cooled in an insulated large crucible. 


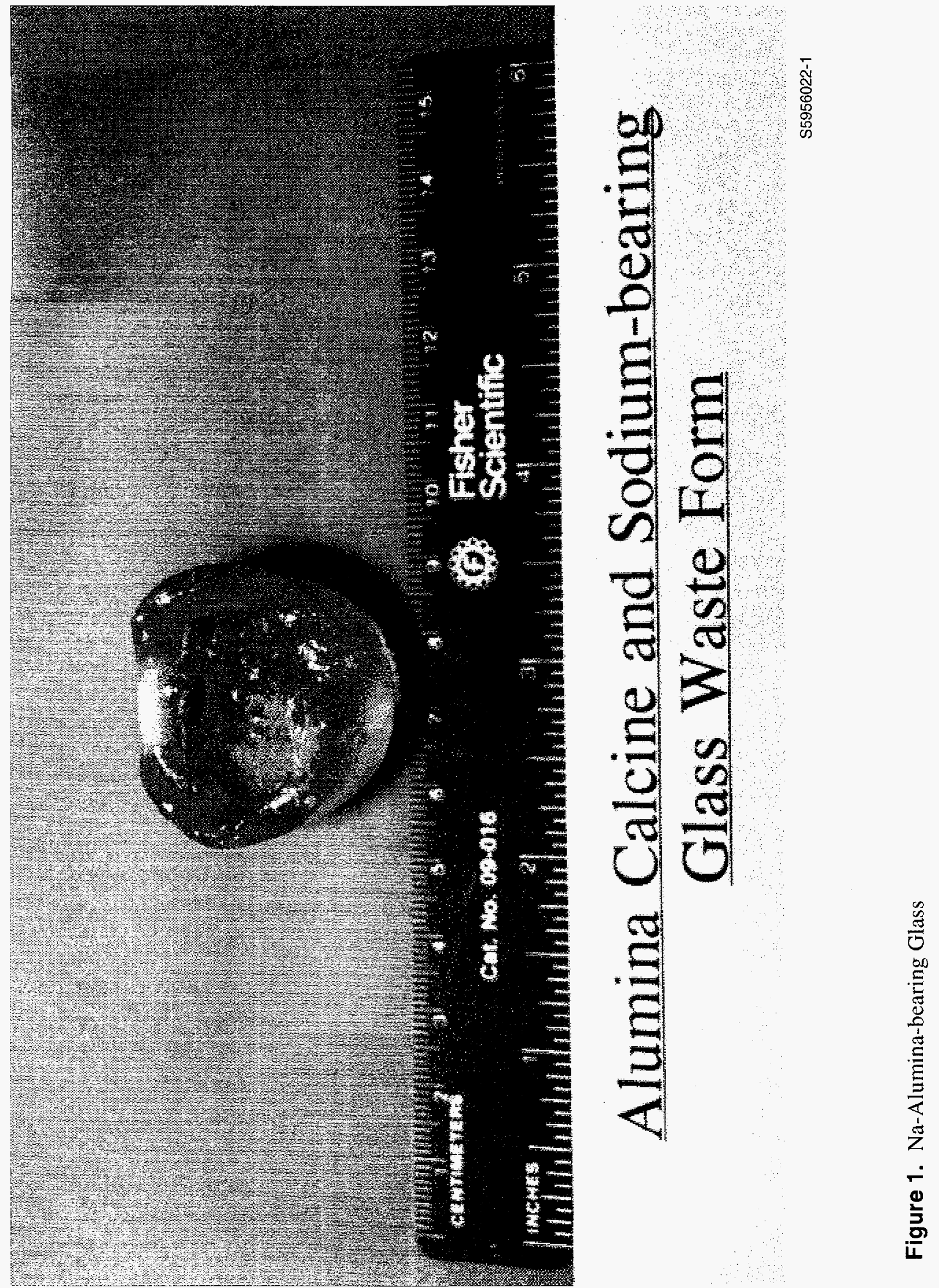


atomic emission spectroscopy (AES), GrindoSonic@ measurements for elastic properties, and scanning electron microscope (SEM) analysis with the associated energy dispersive and wavelength dispersive spectrometers (EDS and WDS) for glass phase composition. Transmission electron microscope (TEM) with selected area diffraction was used to identify any glass phase separation at high magnifications of about $125,000 \mathrm{X}$.

Density

The densities of the glass waste forms were measured using a gas displacement pycnometer and also estimated using the weighted average densities of the component oxides in each waste stream. The measured densities ranged between 2.5 and $2.7 \mathrm{~g} / \mathrm{cm}^{3}$.

Elastic Moduli

Elastic modulus (Young's Modulus) is an important property of a material. If the interatomic force and displacement are expressed in terms of stress and strain, the proportionality constant is called elastic modulus. It is related to the shear modulus and the Poisson's ratio as:

$$
E=2 G(1+v)
$$

where, $\mathrm{E}=$ Young's modulus, $\mathrm{G}=$ shear modulus, and $\mathrm{v}=$ Poisson's ratio. In general, the higher the elastic modulus, the lower the thermal expansion coefficient of the material. A bench top instrument (GrindoSonic@) was used to measure nondestructively the Young's modulus (E), shear modulus (G), and Poisson's ratio $(v)$ of the glasses. The GrindoSonic® instrument measures the longitudinal, flexural, and torsional frequencies of a solid bar or a disc after an impulse excitement. A microphone or a probe "listens" to the vibrations resulting from a simple tap, filters out the noise and harmonics, and displays the fundamental resonant frequency. Computer software calculates the sample density and the elastic properties using the sample frequencies, sample dimensions and the sample mass. The properties are calculated by the computer program after input of frequency, dimensions, and weight of the sample. The elastic moduli were measured for the Na-bearing the and Na-PPT glasses and the values are 10.0 million and 10.6 million psi, respectively. The strength of the material is also proportional to the elastic modulus. Typical room temperature values of the elastic modulus for quartz $\left(\mathrm{SiO}_{2}\right)$ and diamond are $10 \times 10^{6}$ and $114 \times 10^{6} \mathrm{psi}$, respectively. The thermal expansion coefficient for quartz and diamond are $5.2 \times 10^{-6}$, and $1.2 \times 10^{-6} \mathrm{~cm} / \mathrm{cm}^{\circ} \mathrm{C}$, respectively. These elastic moduli suggest that the glasses are of similar strength and of similar thermal expansion coefficient to that of quartz $\left(\mathrm{SiO}_{2}\right)$.

\section{Glass Viscosity}

The viscosity of a glass as a function of temperature and waste loading is the most important variable affecting the melt rate and pourability of the glass. The viscosity also determines the rate of melting of the raw feed, the rate of glass bubble release, the rate of homogenization, and the quality of the glass. If the viscosity is too low, excessive convection currents can occur, increasing the corrosion of the melter components. The lowest viscosity allowed at the Defense Waste Processing Facility (DWPF), Savannah River Site was 20 poise. ${ }^{12}$ Glasses with viscosities $>500$ poise do not readily pour. High viscosity can reduce the product 
quality by causing voids in the final glass. A conservative viscosity range of 20 to 100 poise at a melt temperature of $1150^{\circ} \mathrm{C}$ has been established at DWPF. ${ }^{12}$ The viscosities of the glasses discussed in this report are estimated using the composition, waste loading, and melt (test) temperature. The estimated viscosities are compared in Table 9 with the Savannah River benchmark glass at $35 \mathrm{wt} \%$ loading. Also presented is the composition and the calculated electrical resistivity of the glass waste forms. ${ }^{16}$ The viscosities for Na-Dir.Vit-HAW, Na-PPT-HAW and the Savannah River glasses are all less than the limit of 100 poise for a pourable glass at $1400^{\circ} \mathrm{C}$. For the Na-FC-HAW and the Na-Alumina glasses, the viscosities are high. In-can melting appears appropriate for these high viscosity alumino-silicate glasses. In this process, a canister is heated directly while the glass formulation is fed to the canister. Since the canister itself acts as a melter, the glass is never poured and the viscosity must only be low enough to allow escape of gases and to promote adequate mixing. In addition, each canister acts as a new melter, so, long-term corrosion by the glass may not be a problem. However, the canister must only withstand corrosion incurred during the heating and hydraulic pressure of the molten glass. Fluorides and mercury are known to cause corrosion of the glass melter. Because of low concentrations of $\mathrm{CaF}_{2}$ and $\mathrm{Hg}$, glass melter corrosion may not be expected. Because of the refractory components in the waste, lowering glass viscosity will be difficult. Optimization of the melt viscosity to obtain acceptable reactivity and corrosive properties is required.

\section{Electrical Resistivity}

The electrical resistivity is important to startup and/or restart of Joule-heated electric melters. $^{12}$ At high temperatures the electrical resistivity will be low, and thus glasses conduct electricity. The resistivities of Na-Dir.Vit-HAW, Na-PPT-HAW, and the benchmark Savannah River glass presented in Table 9 are all low (high conductivity) at $1400^{\circ} \mathrm{C}$. Limits were not set for the benchmark Savannah River glasses.

\section{8-day MCC-1 Leach Rates}

The 28-day MCC-1 total mass loss rates (TMLR), and normalized elemental leach rates with surface/volume ratio of $10 \mathrm{~m}^{-1}$, are presented in Table 10 for the Na-bearing glasses. The TMLRs for all the waste forms are low and less than $1 \mathrm{~g} / \mathrm{m}^{2}$-day. Except for $\mathrm{Cr}$ in Na-FC-HAW and $\mathrm{Na}$ in $\mathrm{Na}-\mathrm{PPT}-\mathrm{HAW}$, the normalized elemental leach rates are also low and less than $1 \mathrm{~g} / \mathrm{m}^{2}$-day. As the waste loading was increased from 35 to $50 \mathrm{wt} \%$, the leach rates increased in the Na-Dir.Vit-HAW glasses, but they are all less than $1 \mathrm{~g} / \mathrm{m}^{2}$-day. For the $\mathrm{Na}$-Alumina glass, the normalized elemental leach rates for $\mathrm{Cd}, \mathrm{Cr}, \mathrm{Cs}$, and $\mathrm{K}$ are at a level of the blank leach samples. The normalized elemental leach rates in Na-Alumina glasses are significantly lower than the other Na-bearing glasses. As the temperature increased from 1200 to $1600^{\circ} \mathrm{C}$, the leach rates appear to decrease.

\section{Glass Composition}

The glass compositions for the waste forms were estimated from SEM/EDS data as presented in Tables 11 and 12. The sum of the wt\%s of $\mathrm{Na}_{2} \mathrm{O}, \mathrm{K}_{2} \mathrm{O}$ and $\mathrm{CaO}$ is less than $25 \mathrm{wt} \%$ for all the glasses suggesting that these glasses are chemically durable. The low leach rates are attributed to the high silica content of 53.4-82.8 wt\% as shown in Table 11. This is consistent with the calculated bridging oxygens (BOs) of 1.65, 1.75, 1.90, 1.95 and 2.0 for the 
Table 9. Comparison of Na-bearing Glass Properties with Savannah River Benchmark Glass

\begin{tabular}{|c|c|c|c||}
\hline Glass Waste Form & $\begin{array}{c}\text { Temperature } \\
\text { in }{ }^{\circ} \mathrm{C}\end{array}$ & Viscosity in Poise & $\begin{array}{c}\text { Electrical } \\
\text { Resistivity in } \\
\text { Ohm-cm }\end{array}$ \\
\hline Na-Dir.Vit (35 wt\%) & 1200 & 321 & 2.05 \\
& 1400 & 89 & 0.09 \\
\hline Na-PPT-HAW (35 wt\%) & 1200 & 147 & 1.65 \\
& 1400 & 47 & 0.73 \\
\hline Na-FC-HAW (35 wt\%) & 1200 & 748 & 2.59 \\
& 1400 & 208 & 1.14 \\
\hline Na-Alumina (35 wt\%) & 1200 & 1207 & 2.95 \\
& 1400 & 335 & 1.30 \\
\hline Savannah River & 1200 & 168 & 1.72 \\
Bench Mark Glass (35 wt\%) & 1400 & 49 & 0.75 \\
\hline
\end{tabular}


Table 10. The 28-day MCC-1 Total and Normalized Elemental Leach Rates for the Na-bearing Glasses in $\mathrm{g} / \mathrm{m}^{2}$-day.

\begin{tabular}{|c|c|c|c|c|c|c|c|c|c|c|}
\hline Na-Glass Waste Form & TMLR & Al & B & $\mathrm{Ca}$ & $\mathrm{Cd}$ & $\mathrm{Cr}_{\mathbf{r}}$ & $\mathrm{Cs} / \mathrm{Sr}$ & $\mathbf{K}$ & $\mathrm{Na}$ & Si \\
\hline Na-Dir.Vit-HAW (35 wt\%) & 0.24 & 0.21 & 0.16 & 0.06 & 0.22 & 0.54 & $\mathbf{a}$ & 0.08 & 0.08 & 0.07 \\
\hline Na-Dir.Vit (50 wt\%) & 0.38 & 0.32 & 0.40 & 0.24 & 0.29 & 0.56 & $\mathbf{a}$ & 0.24 & 0.30 & 0.16 \\
\hline Na-PPT-HAW (35 wt\%) & 0.47 & 0.87 & 0.45 & 0.30 & 0.50 & 0.26 & $\mathbf{a}$ & 0.92 & 1.16 & 0.18 \\
\hline Na-FC-HAW (35 wt\%) & 0.20 & 0.15 & 0.16 & 0.01 & 0.00 & 1.16 & $\mathbf{a}$ & 0.12 & 0.14 & 0.08 \\
\hline $\begin{array}{c}1200^{\circ} \mathrm{C} \\
\text { Na-Alumina }^{\mathrm{b}}(20 \mathrm{wt} \%)\end{array}$ & 0.05 & 0.02 & 0.03 & 0.06 & c & c & a & c & 0.04 & 0.02 \\
\hline Na-Alumina ${ }^{b}(30 w t \%)$ & 0.12 & 0.05 & 0.08 & 0.06 & c & c & $\mathbf{a}$ & c & 0.09 & 0.04 \\
\hline Na-Alumina ${ }^{b}(35 w t \%)$ & 0.13 & 0.06 & 0.09 & 0.05 & c & c & $\mathbf{a}$ & c & 0.11 & 0.06 \\
\hline $\begin{array}{c}1600^{\circ} \mathrm{C} \\
\text { Na-Alumina } \\
\text { d }(20 w t \%)\end{array}$ & 0.06 & 0.03 & 0.04 & 0.04 & c & c & $\mathbf{a}$ & c & 0.04 & 0.02 \\
\hline Na-Alumina ${ }^{d}(30 w t \%)$ & 0.09 & 0.04 & 0.07 & 0.08 & c & c & $\mathbf{a}$ & c & 0.08 & 0.04 \\
\hline Na-Alumina ${ }^{d}(35 w t \%)$ & 0.13 & 0.08 & 0.09 & 0.04 & c & c & $\mathbf{a}$ & c & 0.10 & 0.05 \\
\hline
\end{tabular}

" The waste does not contain cesium or strontium.

b Synthesized at $1200^{\circ} \mathrm{C}$ for $2-4$ hours.

c The leach rates are less than or equal to the blank sample.

d Synthesized at $1600^{\circ} \mathrm{C}$ for 2 hours. 
Table 11. Glass Composition (wt\%)

\begin{tabular}{|c|c|c|c|c|c|c|c|c|}
\hline \multirow{2}{*}{$\begin{array}{c}\text { Glass/ } \\
\text { Waste Loading }\end{array}$} & \multicolumn{2}{|c|}{ Na-Dir-Vit-HAW } & \multirow{2}{*}{$\frac{\text { NaFCHAW }}{36 w \%}$} & \multirow{2}{*}{$\frac{\text { Na-PPTHAW }}{35 w \%}$} & \multicolumn{4}{|c|}{ Na-Alumined } \\
\hline & $35 w 1 \%$ & $50 w 1 \%$ & & & & 20 & 30 & 35 wi\% \\
\hline $\mathrm{Al}_{2} \mathrm{O}_{3}$ & 10.0 & 14.7 & 13.8 & 1.7 & $\begin{array}{l}1200^{\circ} \mathrm{C} \\
1600^{\circ} \mathrm{C}\end{array}$ & $\begin{array}{r}9.1 \\
13.3\end{array}$ & $\begin{array}{l}13.9 \\
21.2\end{array}$ & $\begin{array}{l}15.8 \\
20.9\end{array}$ \\
\hline $\mathrm{B}_{2} \mathrm{O}_{3}$ & 3.5 & 2.7 & 3.4 & 6.6 & $\begin{array}{l}1200^{\circ} \mathrm{C} \\
1600^{\circ} \mathrm{C}\end{array}$ & $\begin{array}{l}3.6 \\
6.0\end{array}$ & $\begin{array}{l}3.2 \\
5.1\end{array}$ & $\begin{array}{l}2.8 \\
4.8\end{array}$ \\
\hline $\mathrm{CaF}_{2}$ & 0.0 & 0.0 & 0.0 & 0.0 & & & & \\
\hline $\mathrm{CaO}$ & 0.8 & 1.2 & 0.9 & 0.9 & $\begin{array}{l}1200^{\circ} \mathrm{C} \\
1600^{\circ} \mathrm{C}\end{array}$ & $\begin{array}{l}0.2 \\
0.3\end{array}$ & $\begin{array}{l}0.3 \\
0.5\end{array}$ & $\begin{array}{l}0.2 \\
0.6\end{array}$ \\
\hline $\operatorname{CdO}$ & 0.1 & 0.2 & 0.0 & 0.0 & & & & \\
\hline $\mathrm{Ce}_{2} \mathrm{O}_{3}$ & 0.0 & 0.0 & 1.0 & 0.0 & & & & \\
\hline $\mathrm{Cr}_{2} \mathrm{O}_{3}$ & 0.0 & 0.1 & 0.0 & 0.3 & & & & \\
\hline $\mathrm{Cs}_{2} \mathrm{O}$ & 0.0 & 0.0 & 0.2 & 0.0 & & & & \\
\hline $\mathrm{Fe}_{2} \mathrm{O}_{3}$ & 0.4 & 1.1 & 0.0 & 6.3 & & & & \\
\hline $\mathrm{K}_{2} \mathrm{O}$ & 3.6 & 2.4 & 4.0 & 1.6 & & & & \\
\hline $\mathrm{MnO}_{2}$ & 0.3 & 0.7 & 0.0 & 3.7 & & & & \\
\hline $\mathrm{MoO}_{3}$ & 0.0 & 0.0 & 0.0 & 0.0 & & & & \\
\hline $\mathrm{Na}_{2} \mathrm{O}$ & 17.0 & 22.5 & 9.7 & 10.4 & $\begin{array}{l}1200^{\circ} \mathrm{C} \\
1600^{\circ} \mathrm{C}\end{array}$ & $\begin{array}{l}3.9 \\
8.5\end{array}$ & $\begin{array}{c}10.8 \\
7.3\end{array}$ & $\begin{array}{r}12.3 \\
7.4 \\
\end{array}$ \\
\hline $\mathrm{SiO}_{2}$ & 65.6 & 53.4 & 68.2 & 66.1 & $\begin{array}{l}1200^{\circ} \mathrm{C} \\
1600^{\circ} \mathrm{C} \\
\end{array}$ & $\begin{array}{l}82.8 \\
71.9 \\
\end{array}$ & $\begin{array}{l}71.7 \\
65.9 \\
\end{array}$ & $\begin{array}{l}68.6 \\
66.3 \\
\end{array}$ \\
\hline $\mathrm{ZrO}_{2}$ & 0.1 & 0.5 & 0.0 & 1.1 & $1200^{\circ} \mathrm{C}$ & 0.3 & 0.1 & 0.1 \\
\hline
\end{tabular}

- Boron was estimated.

Boron concentration was not measured using SEM/EDS, but assumed to be equal to the amount in the frit. 
Table 12. Glass Compositions in $\mathrm{Na}_{2} \mathrm{O}-\mathrm{Al}_{2} \mathrm{O}_{3}-\mathrm{SiO}_{2}$ and $\mathrm{Na}_{2} \mathrm{O}-\mathrm{B}_{2} \mathrm{O}_{3}-\mathrm{SiO}_{2}$ Systems in $\mathrm{wt} \%$ and mole\%

\begin{tabular}{|c|c|c|c|c|c|c|c|c|c|c|}
\hline $\begin{array}{c}\text { Glass } \\
\text { Waste Loading } \\
\text { Temperature }\end{array}$ & $\begin{array}{l}\text { Na-Dir-Vit. } \\
35 \mathrm{wt} \% \\
1200^{\circ} \mathrm{C}\end{array}$ & $\begin{array}{l}\text { Na-Dir-Vit. } \\
50 w \% \\
1200^{\circ} \mathrm{C}\end{array}$ & $\begin{array}{l}\text { Na-FC-HAW } \\
35 \text { wt\% } \\
1200^{\circ} \mathrm{C}\end{array}$ & $\begin{array}{l}\text { Na-PPT-HAW } \\
35 \text { Wt\% } \\
1200^{\circ} \mathrm{C}\end{array}$ & $\begin{array}{l}\text { Na-Alumina } \\
20 \mathrm{w} / \% \\
1200^{\circ} \mathrm{C}\end{array}$ & $\begin{array}{l}\text { Na-Alumina } \\
30 \mathrm{w} \% \\
1200^{\circ} \mathrm{C}\end{array}$ & $\begin{array}{c}\text { Na-Alumina } \\
35 \mathrm{wt} \% \\
1200^{\circ} \mathrm{C}\end{array}$ & $\begin{array}{l}\text { Na-Alumina } \\
20 \mathrm{w} \% \\
1600^{\circ} \mathrm{C}\end{array}$ & $\begin{array}{l}\text { Na-Alumina } \\
30 \mathrm{w} \% \\
1600^{\circ} \mathrm{C}\end{array}$ & $\begin{array}{l}\text { Na-Alumina } \\
35 \text { wt\% } \\
1600^{\circ} \mathrm{C}\end{array}$ \\
\hline \multicolumn{11}{|l|}{ Component/wt\% } \\
\hline $\mathrm{SiO}_{2}$ & 70.9 & 59.0 & 74.5 & 84.5 & 86.4 & 74.4 & 70.9 & 76.7 & 69.9 & 70.0 \\
\hline $\mathrm{Na}_{2} \mathrm{O}$ & 18.3 & 24.8 & 10.5 & 13.3 & 4.1 & 11.2 & 12.7 & 14.2 & 22.4 & 22.1 \\
\hline $\mathrm{Al}_{2} \mathrm{O}_{3}$ & 10.8 & 16.2 & 15.0 & 2.2 & 9.5 & 14.4 & 16.4 & 9.1 & 7.7 & 7.9 \\
\hline Total (wT\%) & 100,0 & 100.0 & 100.0 & 100.0 & 100.0 & 100.0 & 100.0 & 100.0 & 100.0 & 100.0 \\
\hline \multicolumn{11}{|l|}{ Component/mole\% } \\
\hline $\mathrm{SiO}_{2}$ & 76.2 & 67.9 & 83.9 & 79.5 & 91.7 & 83.7 & 82.0 & 81.7 & 77.1 & 77.3 \\
\hline $\mathrm{Na}_{2} \mathrm{O}$ & 19.7 & 28.6 & 11.9 & 12.5 & 4.3 & 12.6 & 14.6 & 8.9 & 14.6 & 14.3 \\
\hline $\mathrm{B}_{2} \mathrm{O}_{3}$ & 4.1 & 3.4 & 4.2 & 8.0 & 4.0 & 3.7 & 3.4 & 9.4 & 8.3 & 8.4 \\
\hline Total (mole $\%)$ & 100.0 & 100.0 & 100.0 & 100.0 & 100.0 & 100.0 & 100.0 & 100.0 & 100.0 & 100.0 \\
\hline
\end{tabular}


$35 \mathrm{wt} \%$ Na-PPT-HAW, the $50 \mathrm{wt} \%$ Na-Dir.Vit-HAW, the $35 \mathrm{wt} \%$ Na-Dir.Vit-HAW, the $35 \mathrm{wt} \%$ $\mathrm{Na}-\mathrm{FC}-\mathrm{HAW}$, and the 20-35 wt\% Na-Alumina glasses, respectively. In general, in a durable glass such as quartz $\left(\mathrm{SiO}_{2}\right)$, a three-dimensional network of polyhedra consisting of 2 bridging oxygens per tetrahedra exists.

The structural configuration in alkali alumino silicate glasses depend upon the molar ratio $\left[\mathrm{Al}_{2} \mathrm{O}_{3}\right] /\left[\mathrm{Na}_{2} \mathrm{O}\right] .{ }^{17}$ When the ratio is $<1$, the $\mathrm{Al}^{3+}$ ion acts as a network former having tetrahedral coordination. For the ratio $>1$, the $\mathrm{Al}^{3+}$ ion enters the network as a modifier ion in octahedral coordination. The percent of tetrahedra in each glass was estimated as a sum of the molar percent of silicon and aluminum ions $\left(\left[\mathrm{SiO}_{2}\right]+2 *\left[\mathrm{Al}_{2} \mathrm{O}_{3}\right]\right)$. One of the four rules ${ }^{18}$ for glass formation according to Zachariasen is that at least three corners of the tetrahedral unit are to be shared. The number of corners shared $(Y)$ per tetrahedra is calculated using the formula:

$$
\mathrm{Y}=6-200 /\left(\left[\mathrm{SiO}_{2}\right]+\left[\mathrm{Al}_{2} \mathrm{O}_{3}\right]+\left[\mathrm{B}_{2} \mathrm{O}_{3}\right]\right)
$$

where, [ ] represents the mole percent of the component in the square brackets. The $\left[\mathrm{Al}_{2} \mathrm{O}_{3}\right] /\left[\mathrm{Na}_{2} \mathrm{O}\right]$ ratios, the percent tetrahedra, percent octahedra, and the number of corners shared per tetrahedra for the glasses are presented in Table 13. For the $20 \mathrm{wt} \%$ Na-Alumian glass the ratio was 1.40. Thus the role played by $\mathrm{Al}^{3+}$ ion in these glasses is that of modifier in octahedral coordination. For the Na-FC-HAW, Na-Dir.Vit-HAW, and Na-PPT-HAW glasses the ratios are $0.87,0.40$ or 0.36 and 0.10 , respectively, suggesting that $\mathrm{Al}^{3+}$ plays a glass former role in tetrahedral coordination. The percent of tetrahedra ranged between 78 and $94 \%$ for the glasses for which the ratio $\left[\mathrm{Al}_{2} \mathrm{O}_{3}\right] /\left[\mathrm{Na}_{2} \mathrm{O}\right]$ is $<1$, indicating good durability. The number of corners shared per tetrahedra ranged between 3.2 and 3.9 for the glasses (see Table 13), suggesting that these glasses are good (extended three-dimensional networks lacking periodicity according to the Zachariasen rule No. 4). The glass composition in terms of the ternary phase diagrams for $\mathrm{Na}_{2} \mathrm{O}-\mathrm{Al}_{2} \mathrm{O}_{3}-\mathrm{SiO}_{2}$ and $\mathrm{Na}_{2} \mathrm{O}-\mathrm{B}_{2} \mathrm{O}_{3}-\mathrm{SiO}_{2}$ are presented in Table 12 and shown in Figures 2 and 3 along with the component melting temperatures. ${ }^{18-20}$ In general, the glass compositions lie near the stable components (see Figure 2) for $\mathrm{SiO}_{2}$ (cristobalite), $\mathrm{Na}_{2} \mathrm{O} .2 \mathrm{SiO}_{2}$ and $\mathrm{Na}_{2} \mathrm{O} . \mathrm{Al}_{2} \mathrm{O}_{3} .6 \mathrm{SiO}_{2}$ (albite). The compositions for the significantly most durable Na-Alumina glasses lie near $\mathrm{SiO}_{2}$ (cristobalite). The $50 \mathrm{wt} \%$ Na-Dir.Vit glass (sample 4 in Figure 2) lies below the albite composition because of the high soda content. As shown in Figure 3 in the $\mathrm{Na}_{2} \mathrm{O}-\mathrm{B}_{2} \mathrm{O}_{3}-\mathrm{SiO}_{2}$ diagram, the glass components also lie in the high silica region of the ternary diagram.

A low temperature component called reedmergnerite ${ }^{21}\left(\mathrm{Na}_{2} \mathrm{O} . \mathrm{B}_{2} \mathrm{O}_{3} \cdot 6 \mathrm{SiO}_{2}\right)$ similar to albite (melting at $1118^{\circ} \mathrm{C}$ ), is likely to be formed at $821^{\circ} \mathrm{C}$. The substitution of $\mathrm{B}_{2} \mathrm{O}_{3}$ for $\mathrm{Al}_{2} \mathrm{O}_{3}$ in $\mathrm{Na}_{2} \mathrm{O} . \mathrm{Al}_{2} \mathrm{O}_{3} \cdot 6 \mathrm{SiO}_{2}$ results in $\mathrm{Na}_{2} \mathrm{O} \cdot \mathrm{B}_{2} \mathrm{O}_{3} \cdot 6 \mathrm{SiO}_{2}$; and as a result, the melting point is lowered from 1118 to $821^{\circ} \mathrm{C}$. Comparison of these component diagrams (Figures 2 and 3) suggests that $\mathrm{Al}_{2} \mathrm{O}_{3}$ and $\mathrm{B}_{2} \mathrm{O}_{3}$ play the same role of linked network structure of tetrahedra which appears to be consistent with the estimated tetrahedra. 
Table 13. Structural Parameters for the Glasses

\begin{tabular}{|c|c|c|c|c|c|c|c|c|c|c|}
\hline $\begin{array}{c}\text { Glass/ } \\
\text { Waste Loading } \\
\text { Temperature }\end{array}$ & $\begin{array}{c}\text { Na-Dir-Vit/ } \\
35 w t \% \\
1200^{\circ} \mathrm{C}\end{array}$ & $\begin{array}{c}\text { Na-Dir-Vitt } \\
50 \text { wt\% } \\
1200^{\circ} \mathrm{C}\end{array}$ & $\begin{array}{c}\text { Na-FC-HAW } \\
35 w t \% \\
1200^{\circ} \mathrm{C}\end{array}$ & $\begin{array}{c}\text { Na-PPT-HAW } \\
35 w t \% \\
1200^{\circ} \mathrm{C}\end{array}$ & $\begin{array}{l}\text { Na-Alumina } \\
20 \text { wt\% } \\
1200^{\circ} \mathrm{C}\end{array}$ & $\begin{array}{l}\text { Na-Alumina } \\
30 \mathrm{wt} \% \\
1200^{\circ} \mathrm{C}\end{array}$ & $\begin{array}{l}\text { Na-Alumina } \\
35 \text { wt\% } \\
1200^{\circ} \mathrm{C}\end{array}$ & $\begin{array}{l}\text { Na-Alumina } \\
20 \text { wt\% } \\
1600^{\circ} \mathrm{C}\end{array}$ & $\begin{array}{c}\text { Na-Alumina } \\
30 \mathrm{wt} \% \\
1600^{\circ} \mathrm{C}\end{array}$ & $\begin{array}{l}\text { Na-Alumina } \\
35 w t \% \\
1600^{\circ} \mathrm{C}\end{array}$ \\
\hline$\left[\mathrm{Al}_{2} \mathrm{O}_{3}\right] /\left[\mathrm{Na}_{2} \mathrm{O}\right]$ ratio & 0.36 & 0.40 & 0.87 & 0.10 & 1.4 & 0.79 & 0.78 & 0.94 & 1.8 & 1.7 \\
\hline $\begin{array}{l}\text { Tetrahedra }(\%)^{*} \\
\text { Octahedra }(\%)^{\mathrm{b}}\end{array}$ & $\begin{array}{l}82.6 \\
17.4\end{array}$ & $\begin{array}{l}78.1 \\
21.9\end{array}$ & $\begin{array}{r}91.6 \\
8.4\end{array}$ & $\begin{array}{l}78.0 \\
22.0\end{array}$ & $\begin{array}{r}5.3 \\
94.7\end{array}$ & $\begin{array}{r}94.3 \\
5.7\end{array}$ & $\begin{array}{r}94.2 \\
5.8\end{array}$ & $\begin{array}{r}93.7 \\
6.3\end{array}$ & $\begin{array}{l}11.5 \\
88.5\end{array}$ & $\begin{array}{l}10.8 \\
89.2\end{array}$ \\
\hline $\begin{array}{l}\text { \# of comers } \\
\text { shared } \\
\text { per tetrhedra }\end{array}$ & 3.5 & 3.2 & 3.7 & 3.6 & 3.9 & 3.7 & 3.7 & 3.8 & 3.8 & 3.8 \\
\hline
\end{tabular}

- Tetrahedra for $\left.\left[\mathrm{Al}_{2} \mathrm{O}_{3}\right] / / \mathrm{Na}_{2} \mathrm{O}\right]<1$

- Octahedra for $\left[\mathrm{Al}_{2} \mathrm{O}, y / \mathrm{Na}_{2} \mathrm{O}\right]>1$ 


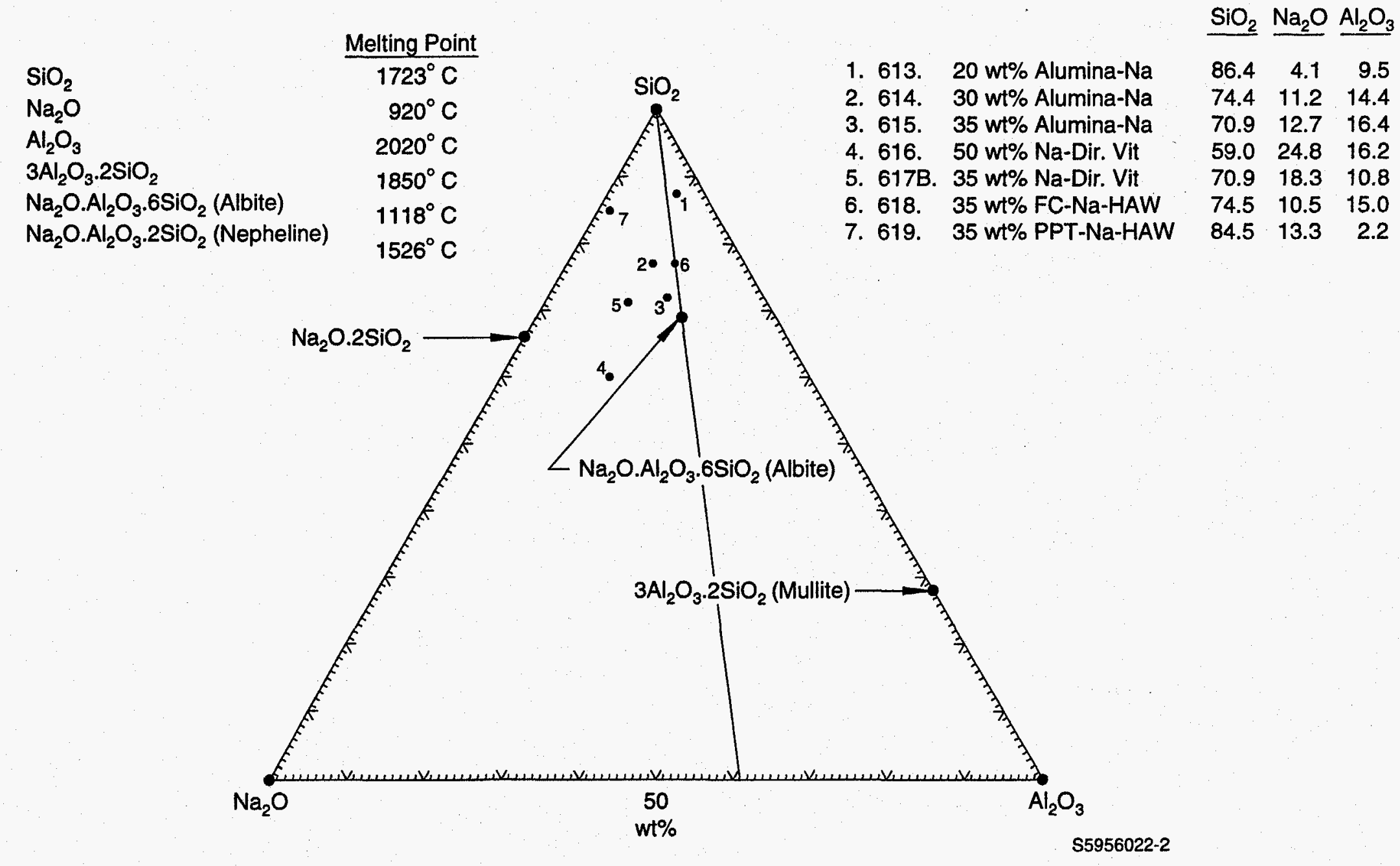

Figure 2. $\mathrm{Na}_{2} \mathrm{O}-\mathrm{Al}_{2} \mathrm{O}_{3}-\mathrm{SiO}_{2}$ Ternary Phase Diagram 


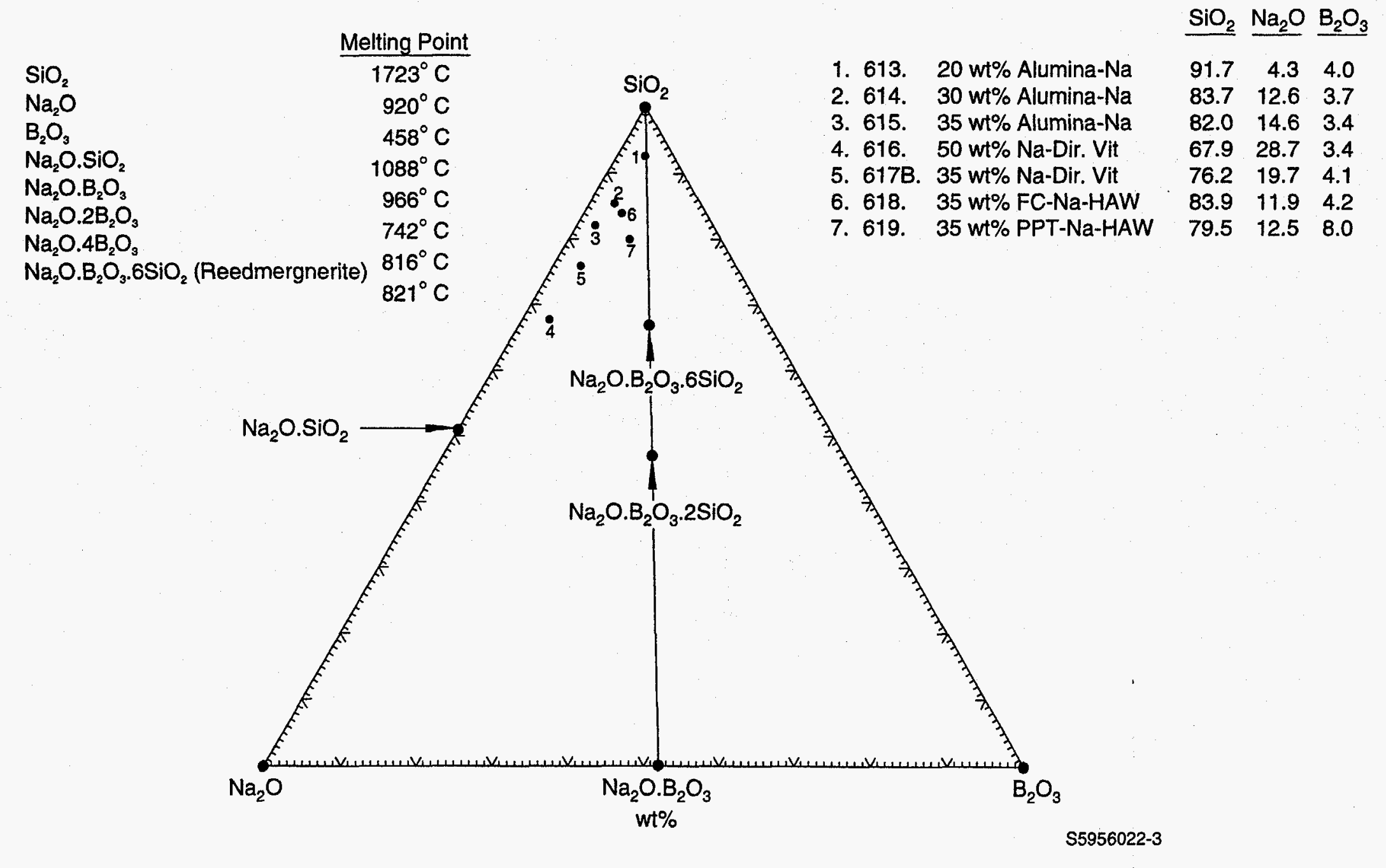

Figure 3. $\mathrm{Na}_{2} \mathrm{O}-\mathrm{B}_{2} \mathrm{O}_{3}-\mathrm{SiO}_{2}$ Ternary Phase Diagram 


\section{Transmission Electron Microscopy}

Transmission Electron Microscopy (TEM) samples were prepared by a combination of mechanical polishing and ion beam thinning. The thin film samples were examined at $125 \mathrm{keV}$ and analyzed by Professor David Howitt and Brenda Zimmny at the University of California, Davis. The $20 \mathrm{wt} \%$ Na-Alumina, $30 \mathrm{wt} \%$ Na-Alumina, $35 \mathrm{wt} \%$ Na-Dir.Vit-HAW, $35 \mathrm{wt} \%$ Na-FC-HAW, and the $35 \mathrm{wt} \%$ Na-PPT-HAW glasses did not appear phase separated when examined at $22,000 \mathrm{X}-125,000 \mathrm{X}$ magnification. The $35 . w t \% \mathrm{Na}$-Alumina and the $50 \mathrm{wt} \%$ Na-Dir.Vit., appear less homogeneous, although most of the microstructure was.developed after exposure to the electron beam. The Wavelength Dispersive Spectrometry (WDS) analysis revealed that boron concentrations are uniform in all but the $35 \mathrm{wt} \% \mathrm{Na}-\mathrm{FC}-\mathrm{HAW}$ glass, and also the oxygen bubbling (electron radiation sensitivity) was very obvious in the $50 \mathrm{wt} \%$ Na-Dir.Vit-HAW glass, clearly apparent in $35 \mathrm{wt} \%$ Na-Dir.Vit., glass but absent in $35 \mathrm{wt} \%$ Na-FC-HAW glass.

\section{CONCLUSIONS AND RECOMMENDATIONS}

Based on the above observations and determinations, the following conclusions and recommendations are made.

1. The Na-Dir.Vit-HAW at $35 \mathrm{wt} \%$ loading appears to be a potential candidate glass waste form for immobilization of the Na-bearing waste.

2. The same frit consisting of $88 \mathrm{wt} \% \mathrm{SiO}_{2}$ and $12 \mathrm{wt} \% \mathrm{~B}_{2} \mathrm{O}_{3}$ may be used for immobilization of the Na-bearing wastes investigated in this report.

3. A blend of $57 \mathrm{wt} \%$ alumina calcined waste in Bin Set 1 and $43 \mathrm{wt} \%$ of the denitrated Na-bearing waste appears to be the best glass formulation for immobilization of both alumina and the Na-bearing wastes (ie., minimum Additive Waste Stabilization (MAWS)).

4. Because of the high $\mathrm{Cr}$ and $\mathrm{Na}$ leach rates at $35 \mathrm{wt} \%$ waste loading, the Na-FC-HAW and the Na-PPT-HAW formulations must be further developed to reduce these leach rates.

5. SEM/EDS examination at $2000 \mathrm{X}$ magnification indicated no devitrification. TEM examination at 125,000 X magnification indicated no phase separation in all the glasses except the $35 \mathrm{wt} \%$ Na-Alumina and the $50 \mathrm{wt} \% \mathrm{Na}$-Dir.Vit., glasses which appeared less homogeneous (although most of the microstructure was developed after exposure to the electron beam).

6. The most durable glasses appeared to be of high viscosity glasses. In general, the glasses appeared to be of too high a viscosity to pour. Optimization of viscosity and chemical durability is necessary if in-can melting is an accepted processing technique. It is recommended to optimize Viscosity and Chemical durability.

7. Because of low concentrations of $\mathrm{CaF}_{2}$ and $\mathrm{Hg}$, glass melter corrosion may not be expected. 
8. Glass structural analysis suggests that tetrahedral or octahedral networks are linked at least greater than three corners, suggesting increased chemical durability. The low normalized elemental leach rates are consistent with the structural analysis.

9. The inerts such as $\mathrm{Al}_{2} \mathrm{O}_{3}, \mathrm{ZrO}_{2}, \mathrm{CaO}$, and $\mathrm{Cr}_{2} \mathrm{O}_{3}$, contribute positive free energies of hydration toward high chemical durability.

10. The glasses appear to be very good candidates for immobilization of the Na-bearing wastes and a blend of Na-bearing waste and the high-level alumina calcined waste.

11. Because of the refractory components in the waste, lowering glass viscosity will be difficult. Optimization of the melt viscosity to obtain acceptable reactivity and corrosive properties is required.

12. Further research and development should be continued to measure glass transition temperatures, TTT diagrams and radiation effects, and to measure visocity and electrical resistivity to validate computer models.

\section{REFERENCES}

1. D. A. Knecht and J. R. Berreth, "Strategy Planning for the Long-Term Management of ICPP High-Level Radioactive Waste," Waste Management 88, September 1989, pp. 837-843.

2. R. S. Baker et al., "Development of a Ceramic-Based Waste Form to Immobilize ICPP HLW," International Symposium on Radioactive Waste Management, ANS Meeting, Niagara Falls, New York, September 14-18, 1986.

3. R. S. Baker and J. R. Berreth, "A Glass-Ceramic Composition to Immobilize ICPP HLW," Proceedings of the 4th Int. Symp. Cer. Nucl. Waste Mgmt., Indianapolis, Indiana 1989, pp 13-22.

4. K. Vinjamuri, "Durability, Mechanical, and Thermal Properties of Experimental Glass-Ceramic Forms For Immobilizing ICPP High Level Waste," 1991 International High-Level Radioactive Waste Management Conference, April 28-May 3, 1991, Las Vegas, Nevada.

5. K. Vinjamuri et al., "Waste Form Development For Immobilization of High Level Waste Calcine at the Idaho Chemical Processing Plant," 1992 International High-Level Radioactive Waste Management Conference, April 12-16, 1992, Las Vegas, Nevada.

6. K. Vinjamuri, "Effect of Aluminum and Silicon Reactants and HIP Soak Time on Characteristics of Glass-Ceramic Waste Forms", American Ceramic Society Symposium, April 18-22, 1993, Cincinnati, Ohio. 
7. K. Vinjamuri, Talc-Silicon Glass-Ceramic Waste Forms for Immobilization of High-Level Calcined Waste, WINCO-1129, June 1993.

8. K. Vinjamuri, Effect of Aluminum and Silicon Reactants and Process Parameters on Glass-Ceramic Waste Form Characteristics For Immobilization of High-Level Fluorinel/Sodium Calcined Waste, WINCO-1133, June 1993.

9. K. Vinjamuri, "Glass-Ceramic Waste forms for Immobilization of Fluorinel/Sodium, Alumina, and Zirconia Calcines Stored at the Idaho Chemical Processing Plant," American Ceramic Society 1994 Annual Meeting, April 24-28, 1994, Indianapolis, Indiana.

10. K. Vinjamuri, "Soil Glass-Ceramic Waste Forms For Immobilization of the Fluorinel/Sodium Calcined High-Level Waste Stored at the Idaho Chemical Processing Plant," SPECTRUM 94, Nuclear and Hazardous Waste Management International Topical Meeting, August 14-18, Atlanta, Georgia.

11. J. A. Murphy, L. F. Pincock, and I. N. Christiansen, ICPP Radioactive Liquid And Calcine Waste Technologies Evaluation Interm Report, WINCO-1216, June 1994.

12. C. M. Jantzen, "First Principle Process-Product Models For Vitrification of Nuclear Waste: Relationship of Glass Composition To Glass Viscosity, Resistivity, Liquid Temperature, and Durability," Ceramic Transactions, Volume 23, Nuclear Waste Management IV, American Ceramic Society, Inc., 1991, pp. 37-51.

13. K. Vinjamuri, "GlassForm A Computer Program to Predict Glass Melt Viscosity, Melt Resistivity, Density, Chemical Durability and Glass Quality Indicators of Glass Waste Forms" (To be published).

14. J. R. Berreth, Westinghouse Idaho Nuclear Company, to D. A. Knecht, Westinghouse Idaho Nuclear Company, Subject: "Basic CERCOMP Instructions for Use", Personal Communication, February 1990.

15. J. E. Mendel (editor), "Test Methods," Nuclear Waste Materials Handbook, DOE/TIC-11400, September 1983.

16. W. T. Goldston and M. J. Plodinec, "The DWPF Strategy for Producing an Acceptable Product," Ceramic Transactions, Volume 23, Nuclear Waste Management IV, American Ceramic Society, Inc., 1991, pp. 443-452.

17. A. K. Varshneya, Fundamentals of Inorganic Glasses, Academic Press, 1993.

18. W. D. Kingery, H. K. Bowen and D. R. Uhlmann, Introduction to Ceramics, John Wiley \& Sons, New York, New York, 1975.

19. E. F. Osborn and A. Muan, Phase Equilibrium Diagrams of Oxide Systems, American Ceramic Society, 1960, Plate 2. 
20. L. H. Van Vlack, Physical Ceramics for Engineers, Addison Wesley, 1964.

21. K. Ghanbari-Ahari and A. M. Cameron, "Phase Diagram of $\mathrm{Na}_{2} \mathrm{O}-\mathrm{B}_{2} \mathrm{O}_{3}-\mathrm{SiO}_{2}$ System," J. Am. Ceram. Soc., 76 [8], 2017-22, 1993. 